\title{
PROPERTIES OF NANOCRYSTALLINE M-TYPE CALCIUM HEXAFERRITE SYNTHESIZED BY SOL-GEL AUTO-COMBUSTION TECHNIQUE
}

\section{P. R. Moharkar*1, S. R. Gawali ${ }^{2}$, R. R. Kherani ${ }^{3}$, K. G. Rewatkar ${ }^{2}$}

${ }^{1 *}$ Deptt of Physics, A. C. S. College, Chandrapur, (M.S.), India (442401)

${ }^{2}$ Deptt Physics, Dr. Ambedkar College, Chandrapur, (M.S.), India (442401)

${ }^{3}$ Deptt of Physics, Shri. Shivaji Science College, Rajura, (M.S.), India (442905)

*Corresponding author's e-mail: pmoharkar103@gmail.com

\begin{abstract}
:
Hexaferrites are industrrially important materials that have numerous technological applications such as permanent magnets, microwave devices, magnetic recording media and magneto-optical devices. Keeping this view, the nanocrystalline aluminium substituted calcium hexaferrites $\mathrm{CaAl}_{\mathrm{x}} \mathrm{Fe}_{12-\mathrm{x}} \mathrm{O}_{19}(\mathrm{x}=3$; 6) have been synthesized using sol-gel autocombustion technique by blending metal nitrates as oxidants accompanied with fuel like urea as reducing agent. The synthesized samples were characterized using XRD, TEM and VSM. XRD study showed that the synthesized samples were single M-type hexagonal ferrites. The effect of substitution of $\mathrm{Al}^{3+}$ ion for $\mathrm{Fe}^{3+}$ ion on the unit cell parameters, density and porosity has been studied. The TEM study showed that the average particle size of the synthesized samples was close to $94 \mathrm{~nm}$. The DC electrical conductivity was measured as a function of temperature from $300 \mathrm{~K}$ to $873 \mathrm{~K}$ using two probe techniques. The phenomenon of conduction was explained on the basis of a Vervey hopping model. The magnetic study reveals that the substitution of $\mathrm{Al}^{3+}$ ion for $\mathrm{Fe}^{3+}$ ion in calcium hexaferrite greatly improves the magnetic parameters.
\end{abstract}

Keywords: M-type hexagonal ferrite, Nanoparticles, magnetic parameters etc.

\section{INTRODUCTION:}

M-type hexagonal ferrites are known for their high uniaxial magnetocrystalline anisotropy with the easy axis of magnetization along the hexagonal c-axis and their chemical stability [1]. These materials have been used in bulk form for many applications due to their hard magnetic properties, for example, as permanent magnets. In the last time these ferrites have drawn a great interest for magnetic recording media 
and microwave devices [2,3]. Hexagonal ferrites show good chemical and thermal stability which would result in longer storage life of the media.

Hexagonal ferrites have been synthesized by using various synthesis routes like chemical coprecipitation [4], low-temperature combustion [5], sol-gel [6], mechanical alloying [7], mechanical activation [8], solid-state reaction [9], microemulsion and reverse microemulsion $[10,11]$, etc. The method of preparation strongly determines the structural and magnetic properties of hexaferrite. An ideal method to synthesize substituted M-type hexaferrite should include the following: facile operation, low anneal or calcine temperature, energy efficient and a short reaction rate, etc. [12].

In current research, M-type calcium hexaferrite has been synthesized by sol-gel auto-combustion method. It is in fact a particularly simple, safe and rapid process where in main advantages are high homogeneity, high purity and time saving and ultra fine powders. In addition, the sol-gel auto-combustion route gives ultra fine powder of nanoparticles with better particle size distribution, excellent chemical homogeneity and more probability of formation of single domain structure [13].

\section{EXPERIMENT}

\section{Sample preparations}

The polycrystalline M-type calcium hexaferrites having the following formula $\mathrm{CaAl}_{\mathrm{x}} \mathrm{Fe}_{12-\mathrm{x}} \mathrm{O}_{19}$, with $\mathrm{x}=3$ and 6 , were prepared by solgel auto-combustion route. All the chemicals used for this synthesis were of analytical grade. The stoichiometric amounts of AR grade $\mathrm{Ca}\left(\mathrm{NO}_{3}\right)_{2} \cdot 4 \mathrm{H}_{2} \mathrm{O}, \mathrm{Fe}\left(\mathrm{NO}_{3}\right)_{3} \cdot 9 \mathrm{H}_{2} \mathrm{O}$, and $\mathrm{Al}\left(\mathrm{NO}_{3}\right)_{3} \cdot 9 \mathrm{H}_{2} \mathrm{O}$ dissolved in triple filtered deionised distilled water at the temperature of $50{ }^{\circ} \mathrm{C}$, were placed in a beaker. These metal nitrates were used as oxidants. The fuel urea $\mathrm{CO}\left(\mathrm{NH}_{2}\right)_{2}$ was also dissolve in deionise water and is used as reducing 
agent to supply requisite energy to initiate exothermic reaction amongst oxidants. All these solutions were mixed together to form homogeneous yellow brown aqueous solution. The homogeneous aqueous solution is then heated in in the digitally controlled microwave oven of $2.45 \mathrm{GHz}$ for 15-20 min so that it get concentrated slowly without producing any precipitation but change its viscosity and colour until it turn $\mathrm{s}$ into brown gel. The gel get burnt by self propagating combustion reaction evolving large volumes of gases and finally get converted in homogeneous nanocrystalline brown powdered sample. The powdered sample was then further annealed by giving intermittent moderate heat treatment for further few minutes with intermediate grinding and quenching in dry air. The sample so produced was then kept in moist free air tight compartment to avoid possible air borne reactions and for the further characterization.

\section{Characterization}

The phase identification of the powdered samples at room temperature was performed by using X-ray diffraction on a (PW 1710) Philips Holland X-ray diffractometer using $\mathrm{Cu}-\mathrm{Ka}$ radiation $(\Lambda=1.5406$ Å). The X-ray diffraction data of the synthesized samples are tabulated in Table1. The lattice constants of the powdered samples were calculated using $\mathrm{d}, \mathrm{h}, \mathrm{k}$, and 1 values of high intensity peaks in the XRD patterns according to the equation

$\frac{a^{2}}{d^{2}}=\frac{4}{3}\left(h^{2}+h k+k^{2}\right)+l^{2} \frac{a^{2}}{c^{2}}$

The cell volume $\left(\mathrm{V}_{\text {cell }}\right)$ of the hexagonal system was calculated as follows $V_{\text {cell }}=0.866 a^{2} c$

where the numeric factor is constant for the hexagonal system. 
Table 1: (a) Sample $\mathrm{CaAl}_{3} \mathrm{Fe}_{9} \mathrm{O}_{19}$ and (b) sample $\mathrm{CaAl}_{6} \mathrm{Fe}_{6} \mathrm{O}_{19}$ : X-ray diffraction data.

a)

\begin{tabular}{|l|l|l|ll|l|}
\hline $\mathbf{2}$ & $\mathbf{d}_{\text {obs }}(\mathbf{\AA})$ & $\mathbf{d}_{\text {cal }}(\mathbf{\AA})$ & $\begin{array}{l}\mathbf{h} \\
\mathbf{1}\end{array}$ & $\mathbf{k}$ & $\mathbf{I} / \mathbf{I o}$ \\
\hline 24.095 & 3.6905 & 3.6905 & 0 & 0 & 41.6 \\
\hline 30.185 & 2.9657 & 2.97862 & 1 & 0 & 12.6 \\
\hline 33.12 & 2.7093 & 2.70941 & $\begin{array}{l}1 \\
6\end{array}$ & 1 & 100 \\
\hline 35.56 & 2.5225 & 2.52252 & $\begin{array}{l}2 \\
0\end{array}$ & 0 & 89.8 \\
\hline 36.94 & 2.4314 & 2.43356 & 5 & 1 & 15.6 \\
\hline 40.9 & 2.2101 & 2.21138 & 9 & 0 & 20 \\
\hline 49.49 & 1.8448 & 1.84525 & $\begin{array}{l}0 \\
12\end{array}$ & 0 & 30.5 \\
\hline 54.12 & 1.6932 & 1.69407 & $\begin{array}{l}2 \\
6\end{array}$ & 1 & 29.1 \\
\hline 61.675 & 1.5064 & 1.50717 & $\begin{array}{l}2 \\
9\end{array}$ & 1 & 11.7 \\
\hline 62.55 & 1.4837 & 1.48489 & $\begin{array}{l}3 \\
7\end{array}$ & 0 & 21.2 \\
\hline 63.995 & 1.4573 & 1.45637 & $\begin{array}{l}2 \\
0\end{array}$ & 2 & 23.7 \\
\hline 72.23 & 1.3069 & 1.30836 & $\begin{array}{l}3 \\
6\end{array}$ & 1 & 6.9 \\
\hline
\end{tabular}

b)

\begin{tabular}{|c|c|c|ccc|c|}
\hline $\mathbf{2} \square$ & $\mathbf{d}_{\text {obs }}(\hat{\mathbf{A}})$ & $\mathbf{d}_{\text {cal }}(\hat{\AA})$ & $\mathbf{h}$ & $\mathbf{k}$ & $\mathbf{1}$ & $\mathbf{I} / \mathbf{I o}$ \\
\hline 24.175 & 3.6784 & 3.67840 & 0 & 0 & 6 & 26.0 \\
\hline 33.170 & 2.7053 & 2.70310 & 1 & 1 & 3 & 100 \\
\hline 35.640 & 2.5170 & 2.51702 & 2 & 0 & 0 & 92.0 \\
\hline 37.210 & 2.4144 & 2.41931 & 1 & 0 & 8 & 18.4 \\
\hline 40.910 & 2.2096 & 2.20704 & 0 & 0 & 10 & 30.4 \\
\hline 49.545 & 1.8429 & 1.84208 & 2 & 1 & 3 & 26.0 \\
\hline 54.205 & 1.6950 & 1.69772 & 0 & 0 & 13 & 48.1 \\
\hline 62.590 & 1.4866 & 1.48500 & 2 & 0 & 12 & 28.2 \\
\hline 64.145 & 1.4506 & 1.45006 & 2 & 2 & 1 & 30.4 \\
\hline 72.435 & 1.3069 & 1.30532 & 3 & 1 & 6 & 6.0 \\
\hline 75.600 & 1.2568 & 1.25647 & 4 & 0 & 1 & 2.0 \\
\hline
\end{tabular}

The average particle size of the samples was examined by a Transmission Electron Microscope (TEM) (Philips Model CM 200) operating at 20-200 KV with resolution $2.4 \AA$.

In general, the electrical properties of the ferrite materials depend upon chemical composition, methods of preparation, sintering temperature, and grain size, etc. Temperature dependent DC electrical resistivity has been measured from $300 \mathrm{~K}$ to $873 \mathrm{~K}$. DC electrical resistivity as a function of temperature may be written as follows [14]:

$\rho=\rho_{0} \exp \left(\frac{E_{a}}{k_{B} T}\right)$ 
where $\rho$ is the DC electrical resistivity at temperature $T, \rho_{0}$ is resistivity extrapolated to $1 / T=0, E_{\mathrm{a}}$ is the activation energy and $k_{\mathrm{B}}$ is the Boltzmann's constant.

The magnetic measurements of the aluminium substituted calcium hexaferrite samples were performed by a vibrating sample magnetometer (Lakeshore 665).

\section{RESULTS AND DISCUSSION:}

\section{XRD analysis}

The diffraction patterns of samples are shown in Fig. 1. The XRD data is analyzed by using computer softwares PowderX. By comparing the patterns with JCPDS standards, the phases in the different samples are determined. It is being observed that most of the hexagonal grains are of same size. Using $2 \square$, observed d-values and intensity calculations, $\mathrm{d}$-value is recalculated and (h k l) planes are finalized. The values shown in Table $1(\mathrm{a})$ and (b) confirm the formation of single phase $\mathrm{M}$-type hexagonal ferrites. As calculated, the lattice parameters a, c, $\mathrm{V}_{\text {cell }}$ and $\mathrm{c} / \mathrm{a}$ ratio of the powdered samples are listed in the Table 2. Lattice parameters a and $\mathrm{c}$ are found to be $5.8255 \AA$ and $22.143 \AA$ for sample $\mathrm{CaAl}_{3} \mathrm{Fe}_{9} \mathrm{O}_{19}$ and $5.8128 \AA$ and $22.0704 \AA$ for sample $\mathrm{CaAl}_{6} \mathrm{Fe}_{6} \mathrm{O}_{19}$, respectively. The space group for the samples is observed to be $\mathrm{P}_{3} / \mathrm{mmc}$. The lattice parameters of the samples decrease as the concentration of aluminum increases in the calcium hexaferrites. 
a)

b)
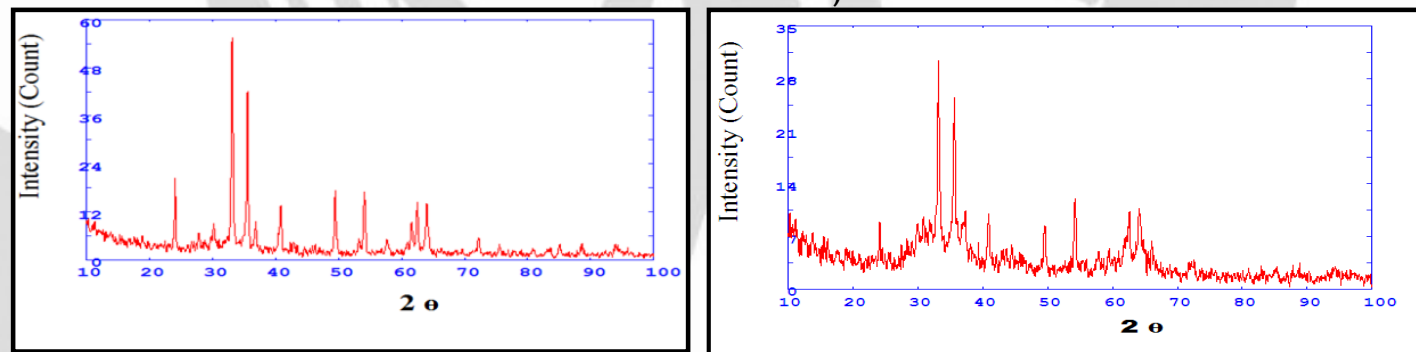

Fig. 1.(a) Sample $\mathrm{CaAl}_{3} \mathrm{Fe}_{9} \mathrm{O}_{19}$ and (b) sample $\mathrm{CaAl}_{6} \mathrm{Fe}_{6} \mathrm{O}_{19}: \mathrm{X}-$ ray diffraction spectra.

Table 2: Lattice constants a and $\mathrm{c}, \mathrm{c} / \mathrm{a}$ ratio and cell volume ( $\left.\mathrm{V}_{\text {cell }}\right)$ of the samples

\begin{tabular}{|c|c|c|c|c|c|}
\hline $\begin{array}{c}\text { Substituti } \\
\text { on }\end{array}$ & $\begin{array}{c}\text { Compoun } \\
\mathbf{d}\end{array}$ & $\mathbf{a}(\mathbf{\AA})$ & $\mathbf{c}(\mathbf{\AA})$ & $\mathbf{c} / \mathbf{a}$ ratio & $\mathbf{V}_{\text {cell }}(\boldsymbol{\AA})$ \\
\hline $\mathrm{x}=3$ & $\begin{array}{c}\mathrm{CaAl}_{3} \mathrm{Fe}_{9} \mathrm{O} \\
19\end{array}$ & $\begin{array}{c}5.825 \\
5\end{array}$ & $\begin{array}{c}22.143 \\
0\end{array}$ & 3.8010 & 647.3361 \\
\hline $\mathrm{x}=6$ & $\begin{array}{c}\mathrm{CaAl}_{6} \mathrm{Fe}_{6} \mathrm{O} \\
19\end{array}$ & $\begin{array}{c}5.812 \\
8\end{array}$ & $\begin{array}{c}22.070 \\
4\end{array}$ & 3.7968 & 645.9090 \\
\hline
\end{tabular}

The lattice parameter ' $a$ ' and ' $c$ ' decreases with increase in the concentration of $\mathrm{Al}^{3+}$ ion. This is due to relatively small ionic radius of $\mathrm{Al}^{3+}$ $(0.53 \AA)$ comparing to that of $\mathrm{Fe}^{3+}(0.64 \AA)$ for six fold coordination. As a result, the cell volume of calcium hexaferrites samples decreases after being doped with $\mathrm{Al}^{3+}$ ion. These results agree well to that reported by Ounnunkad and Winotai [15] and Rewatkar [16] for Co-Al substituted calcium ferrite. Similar trend of lattice parameters and cell volume was reported by Sang Won Lee [17] in La-Zn substituted Strontium ferrite. 


\section{TEM analysis}

Fig 2 shows TEM photographs of aluminium substituted calcium hexaferrite. The particle size of the hexaferrite samples synthesized by sol-gel auto-combustion technique is in nano-size with an average diameter of $94 \mathrm{~nm}$.

(a)

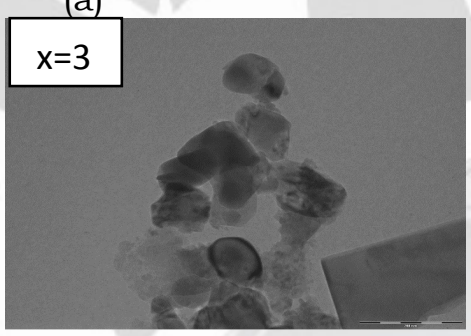

Fig.2: TEM micrographs of $\mathrm{CaAl}_{\mathrm{x}} \mathrm{Fe}_{12-\mathrm{x}} \mathrm{O}_{19}$ : (a) $\mathrm{x}=3$ and (b) $\mathrm{x}=6$ (c)

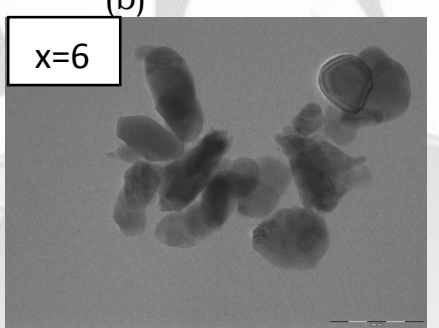

\section{DC conductivity}

Fig. 3 shows that by increasing temperature, the conductivity of ferrite increases, indicating that these ferrites have semiconductors like behavior [14]. The conduction in ferrite at room temperature is due to the impurities, where as at high temperature it is due to polaron hopping [18]. The conductivity in ferrites may be explained by Verwey's hopping mechanism [18]. According to Verwey, the electronic conduction in ferrite is mainly due to hopping of electrons between ions of the same element present in more than one valence state, distributed randomly over crystallographically different lattice sites. The M-type ferrite crystallizes in a hexagonal structure with 64 ions per unit cell on 11 different symmetry sites. The $24 \mathrm{Fe}^{3+}$ atoms are distributed over five distinct sites: three octahedral $(B)$ sites $\left(12 \mathrm{k}, 2 \mathrm{a}\right.$ and $\left.4 \mathrm{f}_{2}\right)$, one tetrahedral $(A)$ site $\left(4 \mathrm{f}_{1}\right)$ and one new type of interstitial $(\mathrm{C})$ site $(2 \mathrm{~b})$ which is not found with spinel and is surrounded by five oxygen ions constituting a trigonal bipyramid. In the hexagonal structure two tetrahedral sites are adjacent to each other and for these two only one metal ion is available. This metal ion now occupies position halfway between them, amidst the three oxygen ions. The distance between two metal ions at (B) site is smaller than the distance between a metal ion at (B) site and another metal ion at (A) site. The electron hopping between (A) and (B) sites under normal conditions therefore has a very small probability compared 
with that for (B)-(B) hopping. Hopping between (A)-(A) sites does not exist for the simple reason that there are only $\mathrm{Fe}^{3+}$ ions at $(\mathrm{A})$ site and any $\mathrm{Fe}^{2+}$ ions formed during processing preferentially occupy (B) sites only. The hopping probability depends upon the separation between ions involved and the activation energy [19]. So, at high temperature, the hopping between $\mathrm{Fe}^{2+} \leftrightarrow \mathrm{Fe}^{3+}$ and $\mathrm{Al}^{2+} \leftrightarrow \mathrm{Al}^{3+}$ is also possible. Hence the conductivity of the samples increase with increase in temperature.

The resistivity of the samples at room temperature increases from $22.0 \mathrm{M} \Omega$ to $25.6 \mathrm{M} \Omega$. The increase in resistivity may be due to the fact that $\mathrm{Al}$ is more resistive than $\mathrm{Fe}$ [19]. The increase in activation energy may be attributed to the creation of more cations and developing of oxygen vacancies, which might have become productive due to rise in temperature. It is concluded that concentration of oxygen vacancies is an important factor in sintering process as well as in DC electrical resistivity [15].

a)

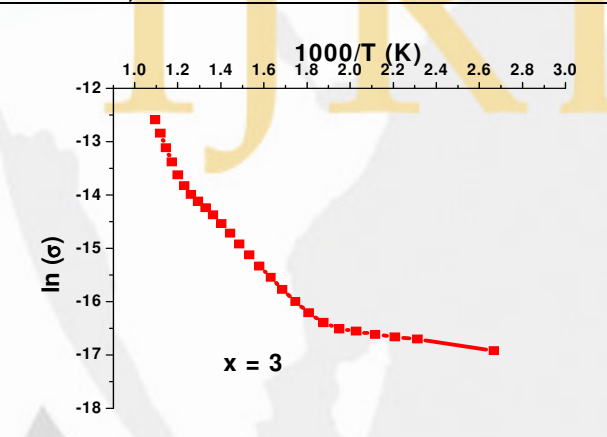

b)

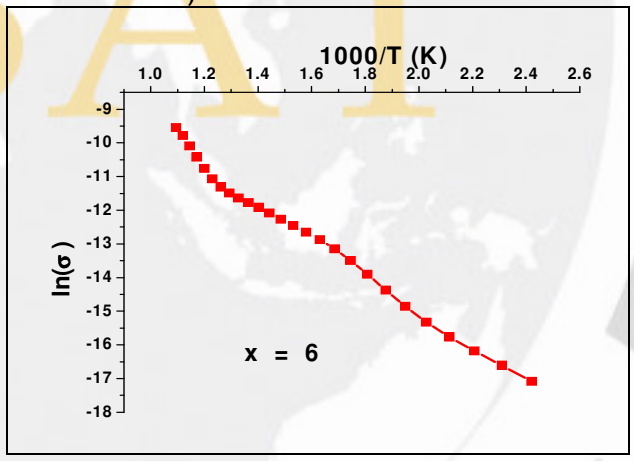

Fig. 3: Variation of $\ln (\sigma)$ with temperature $\left(10^{3} / \mathrm{T}\right)$ of $\mathrm{CaAl}_{\mathrm{x}} \mathrm{Fe}_{12-\mathrm{x}} \mathrm{O}_{19}$ a) $\mathrm{x}=3$ and b) $x=6$.

Table 3: Electrical resistivity at room temperature and activation energy of aluminium substituted calcium ferrite

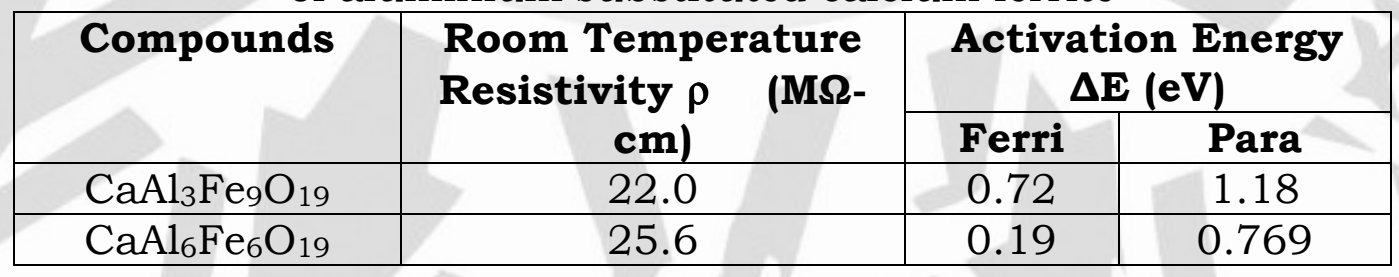




\section{VSM analysis}

The magnet properties of an hexagonal ferrite depend on the intrinsic magnetic properties of the M-type phase. An improvement of the intrinsic magnetic properties of M-type calcium hexaferrites can be obtained by the partial substitution of Al. The magnetization of the both samples of calcium hexaferrite were measured on a VSM at room temperature under an applied field of $15 \mathrm{kOe}$. Fig. 4 shows the hysteresis loops of the samples at room temperature. Table 4 shows the values of magnetic parameters such as saturation magnetization $\left(\mathrm{M}_{\mathrm{s}}\right)$, retentivity $\left(\mathrm{M}_{\mathrm{r}}\right)$ and coercivity $\left(\mathrm{H}_{\mathrm{c}}\right)$ of the samples obtained from the hysteresis loops. In table, the values of saturation magnetization (Ms), retentivity (Mr) and coercivity (Hc) of the samples decreases with increase in the $\mathrm{x}$ values from 3 to 6 . In the magnetic structure of $\mathrm{CaAl}_{\mathrm{x}} \mathrm{Fe}_{12-\mathrm{x}} \mathrm{O}_{19}$, the $\mathrm{Fe}^{3+}$ ions were arrange in five different kinds of spin sublattices, $12 \mathrm{k}, 4 \mathrm{f}_{1}, 4 \mathrm{f}_{2}, 2 \mathrm{a}$ and $2 \mathrm{~b}[20,21]$. The substituent $\mathrm{Al}^{3+}$ ions preferred to enter in the $12 \mathrm{k}$ (octahedral) site which has spin in upward direction. The replacement of $\mathrm{Fe}^{3+}$ by the nonmagnetic ions from the site of upward spin reduce the number of electrons with upward spin and result in decreasing the net magnetic moment as well as the saturation magnetization and retentivity. The decrease in coercivity for the $\mathrm{Al}^{3+}$ ion doped samples is due to the replacement of iron ions from $12 \mathrm{k}$ site to results in a reduction in the magnetocrystalline anisotropy. This consequently decreases the coercivity for the samples of aluminium substituted calcium hexaferrite. Similar variations of the saturation magnetization, remanence and coercivity have also been reported for $\mathrm{Al}$ and $\mathrm{Cr}$ doped barium hexaferrite samples [22-24]. 

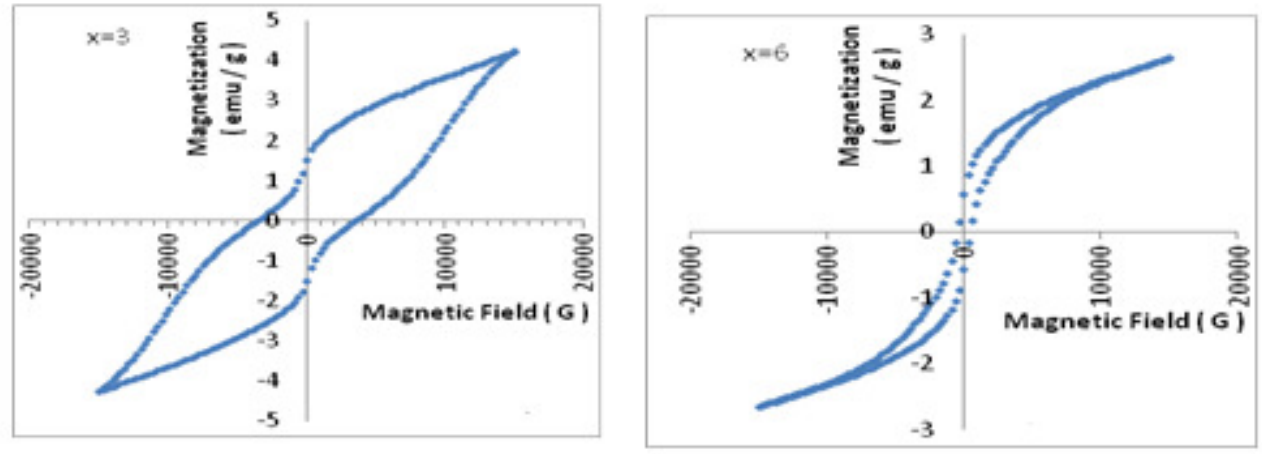

Fig. 4: Hysteresis loops at room temperature:

(a) sample $\mathrm{CaAl}_{3} \mathrm{Fe}_{9} \mathrm{O}_{19}$ and (b) sample $\mathrm{CaAl}_{6} \mathrm{Fe}_{6} \mathrm{O}_{19}$

Table 4: Magnetic parameters of the $\mathrm{CaAl}_{\mathrm{x}} \mathrm{Fe}_{12-\mathrm{x}} \mathrm{O}_{19}$ samples

\begin{tabular}{|c|c|c|c|c|}
\hline Substitution & Compound & $\begin{array}{c}\text { Saturation } \\
\text { Magnetization } \\
\mathbf{M}_{\mathbf{s}} \text { (emu/g) }\end{array}$ & $\begin{array}{c}\text { Retentivity } \\
\mathbf{M}_{\mathbf{r}} \text { (emu/g) }\end{array}$ & $\begin{array}{c}\text { Coercivity } \\
\mathbf{H}_{\mathbf{c}} \text { (Oe) }\end{array}$ \\
\hline $\mathrm{x}=3$ & $\mathrm{CaAl}_{3} \mathrm{Fe}_{9} \mathrm{O}_{19}$ & 4.22 & 1.52 & 3600.02 \\
\hline $\mathrm{x}=6$ & $\mathrm{CaAl}_{6} \mathrm{Fe}_{6} \mathrm{O}_{19}$ & 2.64 & 0.58 & 300.017 \\
\hline
\end{tabular}

CONCLUSION:

The ferrites $\left(\mathrm{CaAl}_{\mathrm{x}} \mathrm{Fe}_{12-\mathrm{x}} \mathrm{O}_{19}\right)$ with $\mathrm{Al}$ substitution were synthesized by sol-gel auto-combustion route. The X-ray diffraction studies confirm the formation of monophase M-typehexaferrites and the a and $c$ values of the sample supports this confirmation. Structural studies have confirmed the space group of the samples to be $\mathrm{P}_{3} / \mathrm{mmc}$. From TEM of the sample, average particle size is found to be in nano-range $(\approx 94 \mathrm{~nm})$. The electrical conductivity of the samples increases with increase in the temperature. The conduction mechanism in calcium ferrite was explained on the basis of Vervey hopping model. The nanorange of particle size of hexaferrites helps to improve many magnetic properties mentioned earlier. The substitution of $\mathrm{Al}^{3+}$ ion for $\mathrm{Fe}^{3+}$ ion greatly improves the magnetic parameters. Such sample specially synthesized by sol-gel auto-combustion route can hold the data confirming their use in storage devices [25]. 


\section{References}

J. Smit, H. P. J. Wijn, (1961), Les Ferrites, Dunod, Paris.

R. G. Simmons, (1989), IEEE Transactions on Magnetics 25, 4051

P. D. Popa, E. Rezlescu, C. Doroftei, N. Rezlescu, J. Optoelectron. (2005).Adv. Mater. 7(3), 1533

S.R. Janasi, M. Emura, F.J.G. Landgraf, D. Rodrigues, (2002) J. Magn. Magn. Mater. 238168.

J. Huang, H. Zhuang, W. Li, J. (2003) Magn. Magn. Mater. 256390.

W. Zhong, W.P. Ding, N. Zhang, J.M. Hong, Q.J. Yan, Y.W. Du, J. (1997)

Magn. Magn. Mater. 168196.

G. Mendoza-Suarez, J.A. Malutes-Aquino, J.I. Escalante-Garcia, H. Mancha-

Molinar, D. Rios-Jara, K.K. Johal, J. Magn. Magn. Mater. 223 (2001) 55.

J. Subrt, J. Tlaskal, (1993) Solid State Ion. 63-65 110.

F. Harberey, A. Kockel, (1976) IEEE Trans. Mag. 13983.

D. Makovec, A. Kosak, A. Znidarsic, M. Drofenik, J. (2005) Magn. Magn.

Mater. 28932.

A. Kosak, D. Makovec, M. Drofenik, (2004) Phys. Stat. Sol. C 1 (12) 3521.

M. Edrissi, R. Norouzbeigi, (2007),Material Science 23 (4)

D. Lisjak, M. Drofenik, (2004) Journal of the European Ceramic Society 24 1845.

T. Abbas, M.U. Islam, M.A. Chaudhry, (1995)Mod. Phys. Lett. B 9 (22) 1419.

S. Ounnunkad , P. Winotai , (2006) J. Magn. Magn. Mater. 301292.

K. G. Rewatkar, N. M. Patil , S. R. Gawali , Bull. (2005) Mater. Sci., 28(6) 585. Sang Won Lee, Sung Yong An, In-Bo Shim, Chul Sung Kim; (2005) J. Magn.

Magn. Mater. 290231.

E.J.W. Verwey, (1936) J.H. De Boer, Rec. Trans. Chem. Des. Pays. Bas. 55531.

A. Lakshman, P.S.V. Subha Rao, B.P. Rao, K.H. Rao, (2005) J. Phys. D. Appl.

Phys. 38673

J. Lipika, (1994) M. Miglierini, J. Electr. Eng. 4512. 
J. Lipika, A. Gruskova, M. Michalikova, M. Miglierini, (1995) J. Slama, I. Thot, J. Magn. Magn. Mater. 1402209.

Q. Q. Fang, H. Cheng, K. Huang, J. Wang, R. Li, Y. Jiao, (2005) J. Magn. Magn. Mater. 294281.

S. Singhal, A. N. Garg, K. Chandra K., (2005) J. Magn. Magn. Mater. 285193.

S. Ounnunkad, P. Winotai, (2006) J. Magn. Magn. Mater. 301292.

D. Schaubert, (2009) The 2008 Antenna Applications Symposium 5224. 